\title{
Robust FDI Determinants in Sub-Saharan African Countries
}

\author{
Nvuh Njoya Youssouf \\ Correspondence: Nvuh Njoya Youssouf, University of Yaounde Ii Soa, Cameroon.
}

\author{
Received: July 17, 2017 \\ Accepted: July 26, $2017 \quad$ Available online: August 3, 2017 \\ doi:10.11114/aef.v4i5.2540 \\ URL: https://doi.org/10.11114/aef.v4i5.2540
}

\begin{abstract}
The aim of this paper is to identify the robustness of the determinants of FDI in sub-Saharan African countries over the period 1985 to 2012. This is done through the use of a linear dynamic panel model, estimated by the Bayesian Averaging of Maximum Likelihood Estimates (BAMLE) developed by Moral Benito (2012). The empirical analysis show the following key results: (i) natural resources and market size are the most robust determinants; (ii) inflation, infrastructure, human capital and trade openness are weak robust; (iii) corruption and political instability are very less robust determinants.
\end{abstract}

Keywords: robust FDI determinants, BAMLE, dynamic panel, sub-Saharan African countries

JEL classification: F21, C23, C13.

\section{Introduction}

Sub-Saharan Africa is recognized as one of the least attractive regions in terms of foreign direct investment (FDI). However, there is an acceleration in inward FDI flows from 2008 with a record level reached in 2012. According to UNCTAD data, the share of sub-Saharan Africa increased from $1.21 \%$ in the $1980 \mathrm{~s}$ to $1.3 \%$ in the late $1990 \mathrm{~s}$, in the $2000 \mathrm{~s}$ it was $1.81 \%$ to $3.06 \%$ in 2012 . In 2015 , this share fell to $2.43 \%$. This slight decrease is related to lower investment in sectors linked to natural resources (WIR, 2016). The low attractiveness of FDI flows in this part of the world has prompted several studies to investigate the causes (Morisset, 2000; Asiedu, 2002, 2004, 2006; Dupasquier and Osakwe, 2006, Anyanwu, 2012).

The theoretical and empirical literature on FDI has identified a large number of variables that can explain inward FDI flows (Faeth, 2009). However, this literature ${ }^{1}$ (Hecksher-Ohlin, 1933; Mundell, 1957; Hymer, 1976; Caves, 1971; Vernon, 1966; Dunning, 1973, 1977, 1981; Brainard, 1993; Krugman and Venables, 1996; etc) does not provide sufficient indication to choose the right empirical model (see Bloningen, 2005). Therefore, there is therefore a problem of selection bias in the model specification. To overcome this problem, a robust analysis of exogenous variables is needed. However, few studies have attempted to assess the robustness of FDI determinants. Among the most recent studies on the subject are studies by Eicher and al (2012) and Blonigen and Piger (2011). To the best of our knowledge, there is no similar work in the specific case of countries in sub-Saharan Africa. This paper aims at identifying the robustness of the determinants of FDI in sub-Saharan Africa.

In this perspective, the paper is organized as follows. The first section deals with the empirical evidence on determinants of FDI in Africa. The second section presents the methodology. The third section is devoted to the data. Finally, we conclude by highlighting results.

\subsection{Empirical Evidence on Determinants of FDI in Africa}

Recent contributions have been made by Anyanwu (2012). This author demonstrated from a sample of 53 African countries over the period 1996-2008 that market size; trade openness, legal framework, official development assistance, agglomeration effects, and natural resources have a positive impact on FDI. Only financial development has a negative effect on the attractiveness of FDI. He also found that the countries of East Africa and those of South Africa were willing to receive more FDI than the other sub-regions. The author used cross-sectional data and implemented ordinary least squares (OLS) and generalized feasible least squares (MCGRs) as an estimation technique.

Krugell and Naudé (2007) identified the determinants of FDI in Africa. By criticizing the different techniques applied to

\footnotetext{
1 See appendix 1
} 
date, they use the method of generalized moments in a step of Arellano and Bond (1991) as an estimator. They identify a number of robust determinants: public consumption, inflation, investment, governance, and literacy.

Asiedu (2006) showed that market size, natural resources, infrastructure quality, low inflation and the legal framework have a positive impact on the attractiveness of FDI. On the other hand, corruption and political instability have the opposite effect. He also found that beyond a country's size and natural resources, a country could attract FDI by improving the quality of its institutions. His analysis covers a panel of 22 countries in sub-Saharan Africa over the period 1984-2000. the author uses a fixed-effect model as an estimation technique.

Dupasquier and Osakwe (2006) described the performance of FDI and provided an explanation for the low attractiveness of FDI in Africa. There are several reasons for this, including political and macroeconomic instability, poor infrastructure, poor governance, increased competition for attracting FDI, an inoperative investment promotion strategy. They propose several recommendations, including more trade and investment between Africa and Asia. They also recommend better support for investors and more incentives for potential investors. Finally, they recommend consultation at the national, regional and international levels in order to attract more FDI and promote growth and development in Africa.

Yasin (2005) established a positive and significant influence of bilateral official development assistance on foreign direct investment. He concludes that beneficiary countries need to develop policies that improve their economic relations with donor countries in order to attract a greater flow of foreign direct investment. The results also show that the growth rate of the labour force, the exchange rate and trade openness have a positive impact on the attractiveness of FDI. However, multilateral development assistance, per capita GDP growth rate, the country's composite risk level, and the index of political freedom and civil liberties do not have a statistically significant effect on FDI. The paper uses panel data from 11 countries in sub-Saharan Africa for the period 1990-2003.

Asiedu (2004) provided an explanation for the low attractiveness of FDI in sub-Saharan Africa. He shows that despite the reforms of its institutions, the improvement in its infrastructure and the liberalization of its regulatory framework for FDI, the performance of sub-Saharan Africa has been mediocre in relative terms. The level of reforms has fallen short of reforms in other developing countries. The author shows that in a competitive global economy, it is not enough to improve political environment. The study is based on a statistical analysis comparing the average performance of sub-Saharan Africa with other developing regions.

Lemi and Asefa (2002) examined the influence of economic and political instability on FDI flows to African economies. They distinguish FDI flows from all countries of the world, those from the United States and those from the US manufacturing and non-manufacturing sectors. They show that the influence of instability on flows from all countries of the world is negligible. For FDI flows from the United States, economic and political instability are not major concerns. For FDI flows from the US manufacturing sector, political instability is an important factor. For FDI flows from the US non-manufacturing sector, the economic, political and host country debt burden are the main constraints to the attractiveness of FDI. They also show that other economic factors such as labor, trade linkages, export size, external debt and market size affect the flow of FDI towards African economies. The study is based on an estimate of a fixed effects model with panel data over a period of 1987 to 1999 for global FDI, and from 1987 to 1998 for US FDI. The authors use the GARCH model to generate instability indicators. This comprises the rate of inflation and the real exchange rate. The analysis covers 32 African countries.

Bende-Nabende (2002) identified the determinants of FDI in sub-Saharan Africa. Through a cointegration analysis, he studies the long-term relationships between FDI and its determinants. Its results suggest that the most relevant long-term determinants of FDI are: market dynamism, openness to exports and liberalization of FDI policy. The other determinants comprise the real exchange rate and the size of the market. The least relevant variable is trade openness. The long-term relationship between FDI and its determinants can be improved in sub-Saharan Africa through better macroeconomic management, liberalization of FDI regimes and expansion of export bases. The study includes 19 countries in sub-Saharan Africa during the period 1970-2000 and uses cross-sectional data and panel data.

Asiedu (2002) analyzed the determinants of FDI in developing countries. It compares whether these factors of attractiveness are different for sub-Saharan Africa. Based on an Ordinary Least Squares (OLS) estimate, his main findings are that countries in sub-Saharan Africa have on average received less FDI than other regions of the world. A high return on investment and the development of infrastructure have a positive and significant impact on the attractiveness of FDI in developing countries without sub-Saharan African countries. In the same time, trade openness has a positive influence on FDI flows in developing countries with sub-Saharan Africa included. The study is based on cross-sectional data from 71 countries over the period 1988-1997.

Morisset (2000) has shown that, beyond the major determinants of natural resources and the size of the domestic market, improving the business climate contributes considerably to the attractiveness of FDI in some countries of sub-Saharan Africa. His work reveals that the rate of growth of GDP and the rate of trade openness can contribute to the improvement 
of the investment climate. His analysis is done with cross-sectional data and panel data from a sample of 29 African countries over the period 1996-1997.

\section{Methodology}

The link between FDI flows and its explanatory variables can be expressed as follows:

$$
y=\theta X+\varepsilon
$$

Where $y$ is the vector of FDI flows, and $X$ represents a set of FDI determinants. Using the Bayesian terminology, the problem of uncertainty in model specification is addressed by estimating the set of models allowed by the possible combinations of $\mathrm{X}$ and constructing a weighted average of the parameter derived from these estimates. Assuming for example that $\mathrm{X}$ contains $\mathrm{K}$ potential explanatory variables, this implies the estimation of $2^{K}$ combinations of variables and therefore $2^{K}$ models each with a certain probability of being the "true" model. The different models indexed by $M_{j}$ for $j=1, \ldots, 2^{K}$ which all seek to explain D the data. $M_{j}$ depends upon parameters $\theta^{j}$. In cases where many models are being entertained, it is important to be explicit about which model is under consideration. Hence, the posterior for the parameters calculated using $M_{j}$ is written as:

$$
g\left(\theta^{j} \mid D, M_{j}\right)=\frac{f\left(D \mid \theta^{j}, M_{j}\right) g\left(\theta^{j} \mid M_{j}\right)}{f\left(D \mid M_{j}\right)}
$$

Thus, the posterior distribution of $\theta$ is an average of the posterior distribution under each model considered, weighted by the posterior probability of these models. For a model $M_{j}$, its a posteriori probability is obtained by using the Bayes rules:

$$
P\left(M_{j} \mid D\right)=\frac{f\left(D \mid M_{j}\right) P\left(M_{j}\right)}{f(D)}
$$

Since $P\left(M_{j}\right)$ does not involve the data, it measures how likely $M_{j}$ is the correct model before seeing the data. The quantity $f\left(D \mid M_{j}\right)$ is the marginal probability of the data, because it is obtained by integrating the joint density of $\left(D, \theta^{j}\right)$ given D over $\theta^{j}$ Moreover, considering $\theta$ a function of $\theta^{j}$ for each $j=1, \ldots, 2^{K}$. We can also calculate the posterior density of the parameters for all the models under consideration:

$$
g(\theta \mid D)=\sum_{j=1}^{2^{K}} P\left(M_{j} \mid D\right) g\left(\theta \mid D, M_{j}\right)
$$

If one is interested in point estimates of the parameters, one common procedure is to take expectations across :

$$
E(\theta \mid D)=\sum_{j=1}^{2^{K}} P\left(M_{j} \mid D\right) E\left(\theta \mid D, M_{j}\right)
$$

Following Leamer (1978), we calculate the posterior variance as:

$$
V(\theta \mid D)=\sum_{j=1}^{2^{K}} P\left(M_{j} \mid D\right) V\left(\theta \mid D, M_{j}\right)+\sum_{j=1}^{2^{K}} P\left(M_{j} \mid D\right)\left(E\left(\theta \mid D, M_{j}\right)-E(\theta \mid D)\right)^{2}
$$


Where $V(\theta \mid D)$ is the posterior variance incorporates. See Raftery (1995) for more details.

Due to the presence of endogeneity (the endogeneity of the lagged dependent variable in dynamic panels), we construct a likehood function. Then we combine maximum likehood estimator with BMA techniques using the BIC approximation in the so-called Bayesian Averaging of Maximum Likehood Estimates (BAMLE) approach. We rewrite $E(\theta \mid D)$ as follows:

$$
E(\theta \mid y)=\sum_{j=1}^{2^{K}} P\left(M_{j} \mid y\right) \hat{\theta}_{M L}
$$

Where $\hat{\theta}_{M L}$ is the maximum likehood estimate for $\theta$ in model j. See moral Benito (2012) for more details.

\section{Data}

For the selection of explanatory variables, we relied on the empirical review of studies on the determinants of FDI in sub-Saharan Africa. There were thirteen explanatory variables that are systematically reported in most major studies (see Appendix 2).

It should be noted that economic theory attaches great importance to the lagged FDI variable. This variable measures the agglomeration effect. Therefore, there is no uncertainty as to the choice of this variable is concerned. It will be used in all possible models with a probability equal to one. The introduction of a lagged variable allows us to extend our model to a dynamic panel. This extension still justifies our choice to use the maximum likelihood estimate that is appropriate for this type of specification.

The natural resource variable is denoted RNAT. It is measured by the income from petroleum, gas and mineral products as a percentage of GDP. Most studies of developing countries show the importance of natural resources in the attractiveness of FDI. For example, Dupasquier and Osakwe (2006), Asiedu (2002) showed that the availability of natural resources has a positive and significant effect on FDI in Africa.

The market size variable is denoted TXPIB. This is one of the most important determinants of FDI. It is generally measured by GDP per capita. Most empirical studies have found that an increase in GDP per capita is accompanied by an increase in inward FDI.

The return on investment variable is denoted RETURN. By definition, FDI converges to countries with the highest return on capital. Due to diminishing returns, the neoclassical theory of growth teaches that return on capital is higher in countries with a lower level of production and capital than their steady state. In Sub-Saharan Africa, as in developing countries, measuring capital returns is problematic given the weak development of the financial market. To overcome this problem, Asiedu (2002) assumes that the marginal productivity of capital is equal to the return on capital. This implies that investment in countries where capital is scarce will yield a higher return. Because countries with scarce capital tend to be poor, Asiedu (2002) uses the inverse of per capita GDP to measure return on capital. This implies ceteris paribus that investments in countries with higher per capita incomes are expected to yield lower returns and hence real GDP per capita should be inversely proportional to FDI. This hypothesis is consistent with the empirical literature.

The infrastructure variable is denoted INFR. It measures the availability of basic infrastructure in the host country. A high level of infrastructure improves investment productivity. It is decisive in the decision to set up foreign firms because in these conditions the operating cost is low. This leads to increasing returns on investment and hence, in FDI. Several proxies are used to measure the level of infrastructure development in the host country. One of them is the number of telephone lines that is used in this paper.

The inflation variable is denoted INFL. It is measured by the consumer price index and apprehends macroeconomic stability. It is also one of the determinants of the attractiveness of FDI in Africa according to Asiedu (2006). High inflation leads to instability and uncertainty in the economy. This situation reduces the expected level of return on investment, as well as the volume of investment. Empirically, several authors find that a high level of inflation attracts less FDI in Africa.

The level of financial development is marked DEVFI. It is measured in most empirical studies by the rate of money and quasi money (M2) as a percentage of GDP.

The human capital variable is denoted KH. It is measured by the rate of enrolment in secondary education as a percentage of crude. Lucas (1990) shows that a low level of human capital is likely to discourage investment. Dunning (1988), Zhang and Markusen (1999) confirm this result and show that a good qualification of the workforce makes a country more attractive to FDI. 
The corruption variable is denoted CORR. It measures the degree of corruption within a political system. Corruption creates distortions in the economic and financial environment, reduces the efficiency of government and business. It covers current or potential corruption in the form of nepotism, excessive patronage, bribery and agreements between politicians and businessmen. Investors cannot bear the additional costs of corruption (which may also indicate the presence of a parallel market). A high score is assigned to the country where there is strong corruption.

The law and order variable is denoted LAW. It measures the impartiality of the legal system and the degree of compliance with the law. It is calculated as the average of judicial independence, impartiality of justice, protection of private property, integrity of the legal system and military interference. Investors opt for countries where their rights are respected. A high score is an impartial judicial system.

The political instability variable is noted INSTP. It is measured by the political risk variable of the ICRG database. It is also one of the important determinants of FDI. It induces uncertainty reflecting political changes. Asiedu (2006) shows that political instability deteriorates the attractiveness of FDI in Africa.

The real exchange rate variable is denoted TXCR. It may prove to be an important factor in international FDI flows. It measures international competitiveness. However, its impact seems ambiguous as evidenced by the theoretical and empirical literature on the issue. Thus, if a real depreciation of the currency negatively affects investments in the short term, the long-term effect may prove positive (Serven and Solimano, 1992). This raises the problem of devaluation, the implementation of which, with the depreciation of the currency, aims to improve international competitiveness in the medium and long term.

The ODA variable is denoted APD. It is measured by official development assistance as a percentage of GNI. Little research has been done to determine the degree of influence of ODA on FDI flows. Yasin (2005), based on a sample of African countries shows a positive effect. Official development assistance can be a catalyst for foreign direct investment. It improves the conditions for internal investment by strengthening the banking and financial systems to promote savings collection and the quality of resource allocation and facilitates the implementation of the public-private partnership.

The trade openness variable is noted OPEN. It is measured using the indicator proposed by Squalli and Wilson (2011). As they point out in their article, this indicator does not purport to provide a perfect measure of trade openness or to remove all controversies related to the traditional measure. On the contrary, this indicator simply reveals a measure that provides results that best reflect the reality in terms of real trade flows in the most open countries.

The data used for the analysis are from WDI, UNCTAD and the ICRG database of the PRS group risk. Observations cover the period 1985-2012 for a set of 36 countries in sub-Saharan Africa. In order to address the problem of serial correlation in the transitory component of the disturbance term, the sample is split in three-year periods. Therefore there are nine observations for each country, that is to say, a sample of 324 observations.

\section{Results}

In table 1, column (1) gives a decreasing indication of the prior inclusion probability (PIP), column (2) shows the prior mean, column (3) gives the prior standard error. Finally, column (4) is a ratio between the mean and the standard error. This report makes it possible to assess the effective contribution of the explanatory variables.

Table 1. Estimation results using the BAMLE approach

\begin{tabular}{lllll}
\hline Variables & PIP $(1)$ & Mean $(2)$ & Standard Error $(3)$ & $(4)=(2) /(3)$ \\
\hline Lagged FDI flow & 1.000 & -0.008 & 0.145 & -0.055 \\
Natural Resources & 0.997 & 0.242 & 0.092 & 2.630 \\
Market size & 0.989 & 0.134 & 0.102 & 1.314 \\
Inflation & 0.754 & -0.054 & 0.189 & -0.286 \\
Infrastructures & 0.702 & 0.111 & 2.672 & 0.042 \\
Human Capital & 0.645 & 0.045 & 0.343 & 0.131 \\
Trade Openness & 0.534 & 0.156 & 0.095 & 1.642 \\
& & 0.106 & 0.276 & 0.384 \\
Law and Order & 0.518 & & & \\
Return on investment & 0.481 & 0.055 & 0.217 & 0.253 \\
Official Development assistance & 0.301 & 0.283 & & 0.193 \\
Financial Development & 0.276 & 0.146 & 1.463 & \\
Corruption & 0.166 & -0.214 & 0.206 & 0.709 \\
Political instability & 0.033 & -0.022 & 0.212 & -1.009 \\
Real Exchange Rate & 0.008 & -0.168 & 0.358 & -0.061 \\
Souce:Autor from & & 1.012 & -0.166 \\
\hline
\end{tabular}

Source: Author from results of Gauss software. 
In the literature, there are several interpretations of the ratio between the mean and the standard error. According to Raftery (1995) if this ratio is greater than 1 in absolute value, the contribution of the explanatory variable is effective. According to Sala-i-Martin et al. (2004), this ratio must be greater than 2 in absolute terms, while according to Masanjala and Papageorgiou (2008), this ratio must be greater than 1.3.

According to the criterion of Raftery (2005), only three exogenous variables are significant: natural resources, market size, trade openness. By retaining, that of Masanjala and Papageorgiou (2008), the three variables remain significant. By retaining, the criterion of Sala-i-Martin et al. (2004), only natural resources are contributory. It should be noted that despite having set 1 as the probability of inclusion of the lagged endogenous variable, it is not significant. Indeed, its ratio is 0.055 in absolute value.

Analyzing the prior inclusion probability, we recall that Raftery (1995) distinguishes four categories of variables. Those between $50-75 \%$ are low, those between $75-95 \%$ are not very robust, those between $95-99 \%$ are robust, and those strictly superior to $99 \%$ are very robust. According to these criteria, natural resources are very robust in terms of our variables. The size of the market is robust. Inflation is a significant variable. Infrastructure, human capital, trade openness, and law and order are weak. For the rest of the variables, they are less likely to be part of the real model as summarized in Table 2.

Table 2. Summary of the significance of results from BAMLE

\begin{tabular}{lll}
\hline Variables & Prior Inclusion Probability (1) & Robust Test \\
\hline Lagged FDI flow & 1.000 & - \\
Natural Resources & $0,997 * * *$ & VeryRobust \\
Market size & $0,989^{* *}$ & Robust \\
Inflation & 0,754 & lowRobust \\
Infrastructures & 0,702 & Weak \\
Human Capital & 0,645 & Weak \\
Trade Openness & $0,534 * *$ & Weak \\
Law and order & 0,518 & Weak \\
Return on investment & 0,481 & VeryWeak \\
Official development assistance & 0,301 & VeryWeak \\
Financial development & 0,276 & VeryWeak \\
Corruption & $0,166^{*}$ & VeryWeak \\
Political instability & 0,033 & VeryWeak \\
Real Exchange rate & 0,008 & VeryWeak \\
\hline * Significant at one threshold criterion, ** significant at two threshold criteria, *** significant at three \\
threshold criteria. \\
\hline
\end{tabular}

Source: Author from results of Gauss software.

By combining robustness with the significance of variables, it can be seen that market size and natural resources are both robust and significant variables. This result is consistent with the results of Morisset (2000), Asiedu (2006), Dupasquier and Osakwe (2006) and Anyanwu (2012). Although these authors do not perform robustness analysis, they nevertheless confirm that these two factors are the main factors determining the attractiveness of FDI in sub-Saharan Africa. As for the trade openness variable, despite its low robustness, it has a significant influence on FDI flows. Institutional variables have a very low likelihood of inclusion. Only the corruption factor is significant compared to other institutional variables (law and order, political instability). This is in contrast to most studies (e.g., Asiedu (2002) and Anyanwu (2012)), which consider institutional factors as contributing significantly to the inflow of FDI.

In terms of economic policy implications, we formulate, following the results, a principal recommendation concerning a diversification of the destination of inward FDI flows in sub-Saharan Africa. This recommendation would thus respond to the dependence of these economies on natural endowments.

\section{Conclusion}

This paper investigates the robustness of FDI determinants in Sub-Saharan African countries over the period 1985 to 2012. We have drawn inspiration from recent work by Moral-Benito (2012). Based on a sample of 36 countries over the period 1985-2012, we analyzed thirteen variables through the Bayesian Averaging of Maximum Likelihood Estimates. The results confirmed that natural resources and market size are the most robust determinants; inflation, infrastructure, human capital and trade openness are weak robust; while corruption and political instability are very less robust determinants. Finally, we recommended a diversification of the destination of inward FDI flows in sub-Saharan Africa. 


\section{Appendix}

Appendix 1: Main FDI theories

\begin{tabular}{|c|c|c|c|c|}
\hline \multicolumn{5}{|c|}{ Main FDI Theories } \\
\hline \multirow{12}{*}{$\begin{array}{l}\text { Neoclassical } \\
\text { Theory of } \\
\text { International } \\
\text { trade }\end{array}$} & \multirow{4}{*}{ International Trade Theory } & Heckscher (1919) Ohlin (1933) & & \\
\hline & & Mundell (1957) & & \\
\hline & & MacDougall (1960) & & \\
\hline & & Kemp ( 1964) & & \\
\hline & \multirow{3}{*}{ Theory of Monopolistic Competition } & Hymer (1976) & & \\
\hline & & Kindleberger (1969) & & \\
\hline & & Caves (1971) & & \\
\hline & Theory of Oligopolistic Reaction & Knickerbocker (1973) & & \\
\hline & Product Life Cycle Model & Vernon (1966) & & \\
\hline & Transaction Cost and Internalization Theory & Buckley and Casson (1976) & & \\
\hline & Currency Area Theory & Aliber (1970) & & \\
\hline & Eclectic Paradigm : the OLI Framework & Dunning $(1977,1980,1981,1988)$ & & \\
\hline \multirow{10}{*}{$\begin{array}{l}\text { New Theory } \\
\text { of } \\
\text { International } \\
\text { Trade }\end{array}$} & \multirow{3}{*}{ Vertical FDI Theory } & Helpman $(1984,1985)$ & & \\
\hline & & Helpman and Krugman (1985) & & \\
\hline & & Grossman and Helpman (2002) & & \\
\hline & \multirow{3}{*}{ Horizontal FDI Theory } & Markusen (1984) & & \\
\hline & & Ethier (1986) & & \\
\hline & & $\begin{array}{l}\text { Horstmann and Markusen } \\
\text { Markusen and Venables (1998) }\end{array}$ & (1987, & 1992) \\
\hline & Proximity-Concentration Trade off & Brainard (1993) & & \\
\hline & \multirow{2}{*}{ Capital Knowledge Model } & Markusen (1997) & & \\
\hline & & Markusen and Venables (1996) & & \\
\hline & New Economic Geography Approach & $\begin{array}{l}\text { Krugman }(1991) \\
\text { Krugman and Venables }(1995,1996)\end{array}$ & & \\
\hline
\end{tabular}

Source: Author

Appendix 2: List of explanatories variables

\begin{tabular}{lll}
\hline Exogenous Variables & Source & References \\
\hline Market size & WDI & $\begin{array}{l}\text { Morisset (2000), Asiedu (2002, 2006), Yasin (2005) Dupasquier } \\
\text { Osakwe (2006), Hailu (2010), Anyanwu (2012) }\end{array}$ \\
Natural Resources & Asiedu (2006) Hailu (2010) Duspaquier et Osakwe (2006), \\
Inflation & WDI & Asiedu (2002, 2006) Krugell and Naude (2007) Hailu (2010) \\
Infrastructures & WDI & Asiedu (2002, 2006) Hailu (2010) \\
Human Capital & WDI & Asiedu (2006) Krugell et Naude (2007) Hailu (2010) \\
Financial Development & WDI & Asiedu (2002) Hailu (2010) \\
Return on investment & WDI & Asiedu (2002), Anyanwu (2012) \\
Official development assistance & WDI & Yasin (2005), Asiedu (2006) \\
Trade Openess & WDI & BendeNabende (2002), Asiedu (2002), Seim (2009), Hailu (2010), \\
Real Exchange Rate & Anyanwu (2012) \\
Political Instability & WDI & Anyanwu (2012) \\
Law and Order & ICRG & Lemi Asefa (2002), Asiedu (2002) Hailu (2010) \\
Corruption & ICRG & Asiedu (2006) \\
\hline
\end{tabular}


Appendix 3: List of Sub-Saharan African Countries

\begin{tabular}{lllll}
\hline List of & Sub-saharan & African Countries & & \\
\hline Angola & Equatorial Guinea & Lesotho & Nigeria & Uganda \\
Benin & Ethiopia & Madagascar & RCA & Zambia \\
Botswana & Gabon & Malawi & RDC & Zimbabwe \\
Burkina Faso & Gambia & Mali & Rwanda & \\
Cameroon & Ghana & Mauritius & Senegal & \\
Cap Verde & Guinea & Mozambique & Sierra Leone & \\
Chad & Ivory Coast & Namibia & South Africa & \\
Congo & Kenya & Niger & Swaziland & \\
\hline
\end{tabular}

\section{References}

Aliber, R. (1970). A Theory of Direct Foreign Investment. In C. Kindleberger (ed.).TheInternational Corporation. Cambridge, MA: MIT Press.

Anyanwu, J. (2012). Why does Foreign Direct Investment go where it goes?: New Evidence From African Countries. Annals of Economics and Finance, 13(2), 433-470.

Asiedu, E. (2002). On the Determinants of Foreign Direct Investment to Developing Countries: Is Africa Different?. World Development, 30(1), 107-119. https://doi.org/10.1016/S0305-750X(01)00100-0

Asiedu, E. (2006). Foreign Direct Investment In Africa: The Role of Natural Ressources, Market Size, Gouvernment Policy, Institution and Political Stability. World Economy, 29(1), 63-77. https://doi.org/10.1111/j.1467-9701.2006.00758.x

Bende-Nabende, A. (2002). Foreign Direct Investment Determinants in Sub-Saharan Africa: A Co-Integration Analysis. Economics Bulletin, 6(4), 1-19.

Blonigen, B. A., \& Piger, J. (2011) Determinants of Foreign Direct Investment NBER,16704.

Bloningen, B. (2005). A review of the empirical literature on FDI determinants.Atlantic Economic Journal, International Atlantic Economic Society, 33(4), 383-403. https://doi.org/10.1007/s11293-005-2868-9

Brainard, S. L. (1993). An Empirical Assessment Of The Factor Proportions Explanation Of Multinationals Sales. NBER Working Paper 4580. Cambridge, MA: National Bureau of Economic Research. https://doi.org/10.3386/w4583

Buckley, P. J. \& Casson, M. (1976). The Future of the Multinational Enterprise. London: Macmillan. https://doi.org/10.1007/978-1-349-02899-3

Caves, R. E. (1971). International Corporations: The Industrial Economics of Foreign Investment. Economica, $38,1-27$. https://doi.org/10.2307/2551748

Dunning, J. H. (1977). Trade, Location of Economic Activity and The MNE: A Search For An Eclectic Approach. In B. Ohlin, P.O. Hesselborn and P.M. Wijkman (Eds), The International Allocation Of Economic Activity, 395-418. London: Holmes and Meier. https://doi.org/10.1007/978-1-349-03196-2_38

Dunning, J. H. (1979). Explaining Changing Pattern of International Production: In Defence of Eclectic Theory.Oxford Bulletin of Economics and Statistics, 41, 269-296. https://doi.org/10.1111/j.1468-0084.1979.mp41004003.x

Dunning, J. H. (1981). International Production and the Multinational Enterprise. London: Allen and Unwin.

Dunning, J. H. (1988). Explaining International Production. London: Allen and Unwin.

Dupasquier, C., \& Osakwe, P. (2006). Foreign Direct Investment in Africa: Performance, Challenges, and Responsabilities,.Journal of Asian Economics, 17(2), 241-260. https://doi.org/10.1016/j.asieco.2005.07.002

Eicher, T., Helfman, L., \& Lenkoski, A. (2012). Robust FDI Determinants: Bayesian Model Averaging In the Presence Of Selection Bias. Journal of Macroeconomics, 34(3), 637-651. https://doi.org/10.1016/j.jmacro.2012.01.010

Ethier, W. (1986). The Multinational Firm. Quarterly Journal of Economics, $101,805-833$. https://doi.org/10.2307/1884179

Faeth, I. (2009). Determinants of Foreign Direct Investment: A Tale of Nine Theoretical Models. Journal of Economic Surveys, 23(1), 165-196. https://doi.org/10.1111/j.1467-6419.2008.00560.x

Grossman, G., \& Helpman, E., (2002). Integration versus Outsourcing in Industry Equilibrium, Quaterly Journal of Economics, 117, 85-120. https://doi.org/10.1162/003355302753399454

Hailu, Z. A. (2010). Demand Side Factors Affecting the Inflow of Foreign Direct Investment to African Countries: Does Capital Market Matter?.International Journal of Business and Management, 5(5), 104-116. 
https://doi.org/10.5539/ijbm.v5n5p104

Heckscher, E. (1919). The Effect of Foreign Trade on the Distribution of Income. Ekonomisk Tidskriff, 497-512. Translated as chapter 13 in American Economic Association,Readings in the Theory of International Trade, Philadelphia: Blakiston, 1949, 272-300, and a new translation is provided in Flam and Flanders.

Helpman, E. (1984). A Simple Theory Of Trade With Multinational Corporations. Journal of Political Economy, 92, 451-471. https://doi.org/10.1086/261236

Helpman, E. (1985). Multinational Corporations And Trade Structure. Review of Economic Studies, 52, 443-458. https://doi.org/10.2307/2297663

Helpman, E., \& Krugman, P. R. (1985). Market Structure and Foreign Trade: Increasing Returns, Imperfect Competition, and the International Economy. The MIT Press, Cambridge, MA.

Hoeting, J. A., Madigan, D., Raftery, A. E., \& Volinsky, C. T. (1999). Bayesian Model Averaging: A Tutorial, Statistical Science, 14(4), 382-417.

Horstmann, I. J., \& Markusen, J. R. (1987). Strategic Investment and The Development Of Multinationals. International Economic Review, 28, 109-121. https://doi.org/10.2307/2526862

Horstmann, I. J., \& Markusen, J. R. (1992). Endogenous Market Structures In International Trade (natura facit saltum). Journal of International Economics, 32, 109-129. https://doi.org/10.1016/0022-1996(92)90038-L

Hymer, S. (1960). The International Operations of National Firms, A study of Direct Foreign Investment. PhD, Dissertation, MIT.11

Kemp, M. C. (1964). The Pure Theory of International Trade. Englewood Cliffs, NJ.Prentice Hall.

Kindleberger, C. P. (1969). American Business Abroad: Six Lectures on Foreign Direct Investment. New Haven. London. Ed. CT: Yale University Press.

Knickerbocker, F. T. (1973). Oligopolistic Reaction and Multinational Enterprise. Boston, MA. Harvard University Press. https://doi.org/10.1002/tie.5060150205

Krugell, W., \& Naudé, W. (2007). Investigating geography and institutions as determinants of foreign direct investment in Africa using panel data, Applied Economics, 39, 1223-1233. https://doi.org/10.1080/00036840600567686

Krugman, P. (1991). Increasing Returns and Economic Geography. Journal of Political Economy, 99(3), 483-499. https://doi.org/10.1086/261763

Krugman, P., \& Venables, A. (1995). Globalization and the Inequality of Nation, QuaterlyJournal of Economics, 110.

Krugman, P., \& Venables, A. (1996). Integration, Specialization and Ajustment, European Economic Review, 40.

Leamer, E. (1978). Specification Searches New York: John Wiley and Sons.

Lemi, A., \& Asefa, S. (2003). Foreign Direct Investment and Uncertainty: Empirical Evidence from Africa. African Finance Journal, 5(1), 36-67.

Lucas, R. E. (1990). Why Doesn't Capital Flow From Rich to Poor Countries ?. The American Economic Review, 80(2), 92-96.

MacDougall, G. D. A. (1960). The Benefits and Costs of Private Investment from Abroad: A Theoretical Approach. Economic Record, 36, 13-35. https://doi.org/10.1111/j.1475-4932.1960.tb00491.x

Madigan, D., \& Raftery, A. E. (1994). Model Selection and Accounting for Model Uncertainty in Graphical Models Using Occam's Window. Journal of The American Staistical Association, 89(428), 1535-1546. https://doi.org/10.1080/01621459.1994.10476894

Madigan, D., \& York, J. (1995). Bayesian Graphical Models for Discrete Data. International Statistical Review, 63, 215-232. https://doi.org/10.2307/1403615

Markusen, J. R. (1984). Multinationals, Multi-Plant Economies, and The Gains From Trade. Journal of International Economics, 16, 205-266. https://doi.org/10.1016/S0022-1996(84)80001-X

Markusen, J. R. (1997). Costly Pollution Abatement, Competitiveness, and Plant Location Decisions, Resource and Energy Economics, Elsevier, 19(4), 299-320.

Markusen, J. R., \& Venables, A. J. (1998). Multinational Firms and The New Trade Theory. Journal of International Economics, 46, 183-203. https://doi.org/10.1016/S0022-1996(97)00052-4

Masanjala, W. H., \& Papageorgiou, C. (2008). Rough and Lonely Road to Prosperity: A reexamination of The Sources of 
Growth in Africa Using Bayesian Model Averaging. Journal of Applied Econometrics, John Wiley \& Sons, Ltd., 23(5), 671-682. https://doi.org/10.1002/jae.1020

Moral-Benito, E. (2012). Determinants of Economic Growth: A Bayesian Panel Data Approach. The Review of Economics and Statistics, MIT Press, 94(2), 566-579. https://doi.org/10.1162/REST_a_00154

Morisset, J. (2000). Foreign Direct Investment In Africa: Policies Also Matter, Transnational Corporations, 9(2), $107-125$.

Mundell, R. (1957). International trade and Factor Mobility. The American Economic Review, 47, 321-335.

Ohlin, B. (1933). Inter-regional and International Trade. Cambridge, Mass: Harvard. University Press, 1966.

Raftery, A. (1995). Bayesian Model Selection in Social Research. Sociological Methodology, 25, 111-163. https://doi.org/10.2307/271063

Raftery, A. E., Madigan, D., \& Hoeting, J. A. (1997). Bayesian Model Averaging for Linear Regression Models. Journal of the American Statistical Association, 92, 179-191. https://doi.org/10.1080/01621459.1997.10473615

Sala-i-Martin, X., Doppelhofer, G., \& Miller, R. (2004). Determinants of Long-Term Growth: A Bayesian Averaging of Classical Estimates (BACE) Approach, American Economic Review, 94, 813-835. https://doi.org/10.1257/0002828042002570

Seim, L. T. (2009). FDI and Openness: Differences in Response across Countries. Chr. Michelsen Institute, Working Paper. 1-34.

Serven, L., \& Solimano, A. (1992). Private Investment and Macroeconomic Adjustment: A Survey. World Bank Research Observer, World Bank Group, 7(1), 95-114. https://doi.org/10.1093/wbro/7.1.95

Squalli, J., \& Wilson, K. (2011). A New Measure Of Trade Openness. The World economic, 1745-1770. https://doi.org/10.1111/j.1467-9701.2011.01404.x

Vernon, R. (1966). International Investment and International Trade In The Product Cycle. Quarterly Journal of Economics, 80, 190-207. https://doi.org/10.2307/1880689

World Investment Report, (2016). Investor Nationality: Policy Challenges.

Yasin, M. (2005). Official Development Assistance and Foreign Direct Investment Flows to Sub-Saharan Africa,.African Development Review, 17(1), 23-40. https://doi.org/10.1111/j.1017-6772.2005.00105.x

Zhang, K. H., \& Markusen, J. R. (1999). Vertical multinationals and host-country characteristics, Journal of Development Economics, Elsevier, 59(2), 233-252. https://doi.org/10.1016/S0304-3878(99)00011-5

\section{Copyrights}

Copyright for this article is retained by the author(s), with first publication rights granted to the journal.

This is an open-access article distributed under the terms and conditions of the Creative Commons Attribution license which permits unrestricted use, distribution, and reproduction in any medium, provided the original work is properly cited. 